\title{
Optimization of Extrusion Conditions and Cooked Vegetable-Chicken Mixture for Instant Banana-Vegetable Soup Powder
}

\author{
Paddy Ainebyona, Julia Kigozi and Ivan M. Mukisa
}

\section{ABSTRACT}

\begin{abstract}
Instant soups are preferred by consumers for their flexibility in preparation and longer storage life. Extrusion cooking is one of the recent developments reported to improve nutrient content of soups. However, little information is available regarding use of extrusion cooking in development of banana vegetable soups. This study investigated the use of extrusion cooking in production of instant banana-vegetable soup. The moisture content was varied using a chicken broth prepared from chicken wings and spicy vegetables (thyme, rosemary, parsley, etc.) to improve flavor and acceptability of the extruded product. The mixture of Banana : Amaranths: pumpkins : mushrooms : carrots $=40.84: 40.84: 9.24: 3.76: 5.34$ was extruded at different moisture content $(10-20 \%)$ and barrel temperature $\left(100-180^{\circ} \mathrm{C}\right)$ and the effect on product responses; reconstitution potential, vitamin $\mathrm{A}$ retention, vitamin $\mathrm{C}$, total fat among other parameters were investigated at constant screw speed $(45 \mathrm{~Hz})$ and feed rate $(50 \mathrm{~Hz})$ to produce an instant banana-vegetables soup. The optimum extrusion temperature and moisture were $123.3^{\circ} \mathrm{C}$ and $10.122 \%$, respectively. The optimal product had a mixture formulation of $60 \%$ extruded flour and $50 \%$ vegetable flour with chicken level at $16.6 \%$. The overall acceptability score, fiber content, fat content, ash content, vitamin $C$ and vitamin $A$ values of the optimum flour were 7.1, $6.8 \%, 11.2 \%, 4.92 \%, 19.4 \mathrm{~g} / 100 \mathrm{~g}$ and $1.21 \mathrm{mg} / 100 \mathrm{~g}$, respectively.
\end{abstract}

Keywords: Acceptability, Extrusion, Moisture content, Temperature.

\author{
Submitted : February 13, 2021 \\ Published : March 9, 2021 \\ ISSN: $2684-1827$ \\ DOI: $10.24018 /$ ejfood.2021.3.2.248 \\ P. Ainebyona \\ Department of Agricultural and \\ Biosystems Engineering, Makerere \\ University, Uganda. \\ (e-mail: painebyona@caes.mak.ac.ug) \\ J. Kigozi \\ Department of Agricultural and \\ Biosystems Engineering, Makerere \\ University, Uganda. \\ (e-mail: jbulyakigozi@yahoo.com) \\ I. M. Mukisa \\ Department of Food Technology and \\ Nutrition, Makerere University, Uganda. \\ (e-mail: ivanmukisa ${ }^{\circledR}$ gmail.com). \\ *Corresponding Author
}

\section{INTRODUCTION}

The global lifestyle of people, characterized by limited cooking time and increased working hours, has led to an increased demand of ready to eat (RTE) products [1]. Extrusion cooking technology has proved to be a commendable process in developing RTE products from cereal flours, tubers and legumes. Examples of such products include breakfast cereals, snacks, porridges, soups, flakes and quick cooking pasta [2]. Like other thermal processing methods, extrusion has effects on nutritional and physicochemical properties [3] and affects the way samples reconstitute during preparation. Extrusion combines a number of unit operations i.e. mixing, cooking, shearing, puffing, final shaping and drying in one energy efficient rapid continuous process [3] to produce the starchy foods. This process requires high temperature short time which causes gelatinization of starch, denaturation of protein, modification of lipid and inactivation of enzymes, microbes and many ant nutritional factors [4]. Extruded foods have been proven to provide nutritious products and combine quality ingredients and nutrients to produce processed foods that contain precise levels of each required nutrient [5].

Extrusion process is known to enhance protein digestibility through protein denaturation of foods, unfolding of polypeptide bonds and reduction in anti-nutritional factors [6]. It also improves mineral bioavailability [7] and results in higher vitamin A retention [8]. Extrusion is known to reduce the resistant starch in green banana flour [9]. The objective of this study was to analyze the effect of extrusion as well as incorporation of chicken vegetable mixture on nutritional properties to promote the utilization of the flour in developing quality soups.

\section{METHODS AND MATERIALS}

\section{A. Raw Material Selection}

\section{Sample preparation for extrusion}

The flour sample Banana : Amaranths : pumpkins : mushroom- m:carrots=40.84:40.84:9.24:3.76:5.34 was weighed to $7 \mathrm{~kg}$ using a standard factory weighing scale and stored at room temperature at Peak Industries, Mukono, Uganda. Chicken broth was prepared using materials in Table I and was refrigerated at $40^{\circ} \mathrm{C}$ at School of Food Technology, Nutrition and Bioengineering (SFTNB) chemistry laboratory, Makerere University Kampala, Uganda. The chicken wings and fresh ingredients shown were obtained from capital Shoppers supermarket, Garden City, Kampala Uganda. Chicken broth was preferred to replace water to improve organoleptic properties of the final product. 
TABLE I: MATERIAL SELECTION FOR PREPARATION OF CHICKEN BROTH

\begin{tabular}{ccc}
\hline No. & Item & Quantity $(\mathrm{g})$ \\
\hline 1 & Chicken wings & 2500 \\
2 & Thyme & 25 \\
3 & Persley & 25 \\
4 & Rosemary & 1, leaves \\
5 & Gallic & 5 \\
6 & Onions & 10 \\
7 & Salt & 10 \\
8 & Water & 7000 \\
\hline
\end{tabular}

\section{B. Experimental Design}

A central composite design (Table II) was used to determine the effect of feed moisture content and barrel temperature on nutritional quality and consumer acceptability of the banana-vegetable flours. The four runs were performed at indicated moisture content and barrel temperature combinations.

TABLE II: CENTRAL COMPOSITE DESIGN USED TO OPTIMIZE FEED

\begin{tabular}{ccc}
\multicolumn{3}{c}{ MOISTURE CONTENT AND BARREL TEMPERATURE } \\
\hline Run & A: Barrel temperature $\left({ }^{\circ} \mathrm{C}\right)$ & B: Feed moisture $(\%)$ \\
\hline 1 & 120 & 10.12 \\
2 & 140 & 14.30 \\
3 & 160 & 17.86 \\
4 & 180 & 15.71 \\
\hline The sample & had Banana: Amaranths: pumpkins: mushrooms:
\end{tabular}

carrots $=40.835: 40.835: 9.24: 3.76: 5.34 ;$ Weight $=7 \mathrm{~kg}$.

The flour was thoroughly mixed with chicken broths using a vertical mixer for 15 minutes and then transferred to a DP70-III double screw inflating food machine (Jinan Eagle Machine Co. Ltd) extruder. Other extruder variables: feed screw speed, feeding rate, cutting rate were kept constant at $45 \mathrm{~Hz}, 40 \mathrm{~Hz}$ and $50 \mathrm{~Hz}$ respectively. After extrusion, the samples were collected and cooled under natural convection to room temperature and then milled using a 30B-C milling machine, the flours were cooled, packed in polythene bags and stored at $4{ }^{\circ} \mathrm{C}$ awaiting nutritional and functional analysis to investigate changes due to extrusion.

\section{Reconstitution of Extruded Flour}

The extruded flour samples were tested to determine their efficiency in reconstituting in hot water. This is due to the fact that extrusion of flours under low moisture content causes greater friction and energy dissipation to the flour resulting into starch degradation and formation of water soluble molecules [9], thus influencing the rate at which the flours reconstitute. Due to limited information regarding reconstitution of extruded soups, an observational approach was adopted to investigate the visual extent of flour reconstitution in hot water. Cold tap water was boiled in a 5 L stainless steel saucepan to $100{ }^{\circ} \mathrm{C}$ using a Total gas cooker. Each sample in measurements of $8 \mathrm{~g}$ obtained using Newwal Kitchen Scale (Model No: NWL-7001, Turkish Origin) was placed in a $3 \mathrm{~L}$ container to which $100 \mathrm{ml}$ of hot water was added. This was followed by uniform frequent stirring using a kitchen mingling stick to form a paste. The procedure followed a standard method for preparation of instant food products [10].

\section{Material Selection for Soup Flavor Enhancement}

The materials indicated in Table III, were carefully selected and purchased from Capital shoppers' supermarket (Kampala, Uganda), parked in paper bags and polythene papers and were stored at $4{ }^{\circ} \mathrm{C}$ at SFTNB Chemistry laboratory awaiting nutritional analysis.

TABLE III: FoRMULATIONS FOR PREPARATION OF CHICKEN VEGETABLE

\begin{tabular}{cccc}
\multicolumn{3}{c}{ MIX } & Formulation \\
\hline \multirow{2}{*}{ Component } & Mix-1 & Mix-2 & Mix-3 \\
\cline { 2 - 4 } & $0.814 \mathrm{~kg}$ & $0.858 \mathrm{~kg}$ & $0.888 \mathrm{~kg}$ \\
Chicken & $2500 \mathrm{mls}$ & $2500 \mathrm{mls}$ & $2500 \mathrm{mls}$ \\
Water & $600 \mathrm{~g}$ & $600 \mathrm{~g}$ & $600 \mathrm{~g}$ \\
Fresh Pumpkin & $20 \mathrm{~g}$ & $20 \mathrm{~g}$ & $20 \mathrm{~g}$ \\
Fresh Carrots & $2 \mathrm{~h}$ & $2 \mathrm{~h}$ & $2 \mathrm{~h}$ \\
Cooking time & $15 \mathrm{~g}$ & $15 \mathrm{~g}$ & $15 \mathrm{~g}$ \\
Onion & $0.5 \mathrm{~g}$ & $0.5 \mathrm{~g}$ & $0.5 \mathrm{~g}$ \\
Rosemary leaves & $1 \mathrm{sprig}$ & $1 \mathrm{sprig}$ & $1 \mathrm{sprig}$ \\
Thyme & $0.5 \mathrm{~g}$ & $0.5 \mathrm{~g}$ & $0.5 \mathrm{~g}$ \\
Basil & $1 \mathrm{stalk}$ & $1 \mathrm{stalk}$ & $1 \mathrm{stalk}$ \\
Dill pp & $5 \mathrm{~g}$ & $5 \mathrm{~g}$ & $5 \mathrm{~g}$ \\
Bay leaves & $5 \mathrm{~g}$ & $5 \mathrm{~g}$ & $5 \mathrm{~g}$ \\
Parsley & $7 \mathrm{~g}$ & $7 \mathrm{~g}$ & $7 \mathrm{~g}$ \\
Gallic & $0 \%$ & $10 \%$ & $20 \%$ \\
Chicken left after & & & \\
cooking & & & \\
& & & \\
\hline
\end{tabular}

\section{E. Method of Preparation}

Chicken samples were first boiled on a gas oven (Total Gas, Uganda) for one hour. The ingredients were weighed in the respective amounts using a Newwal Kitchen Scale (Model No: NWL-7001, Turkish Origin) and mixed in a 5L aluminum source pan. These were added to the chicken and the mixture allowed to boil for 30 minutes. The boiled mixture were left to simmer for 45 minutes. The mixture was then laid on aluminum foils and dried in an air oven for about 48 hours at $60{ }^{\circ} \mathrm{C}$. The dried samples were milled using a Pigeon mixer grinder (Classical lite, Stove Kraft Pvt. Ltd, India) and sieved using a $450 \mu \mathrm{n}$ sieve. The samples were mixed as indicated in Table IV awaiting analysis.

\begin{tabular}{ccccc}
\multicolumn{4}{c}{ TABLE IV: MiXING OF EXTRUDED FlOUR AND VEGETABLE-CHICKEN } \\
\hline \multirow{2}{*}{$\begin{array}{c}\text { Sample } \\
\text { code }\end{array}$} & Extruded flour & \multicolumn{3}{c}{$\begin{array}{c}\text { Vegetable-chicken flour with chicken } \\
\text { meat at }\end{array}$} \\
\cline { 2 - 5 } & Weight $(\mathrm{g} / 100 \mathrm{~g})$ & $\begin{array}{c}0 \% \\
(\mathrm{~g} / 100 \mathrm{~g})\end{array}$ & $\begin{array}{c}10 \% \\
(\mathrm{~g} / 100 \mathrm{~g})\end{array}$ & $\begin{array}{c}20 \% \\
(\mathrm{~g} / 100 \mathrm{~g})\end{array}$ \\
\hline X1 & 50 & 50 & 0 & 0 \\
Y1 & 50 & 50 & 0 & 0 \\
X11 & 60 & 40 & 0 & 0 \\
Y11 & 60 & 40 & 0 & 0 \\
X2 & 50 & 0 & 50 & 0 \\
Y2 & 50 & 0 & 50 & 0 \\
X22 & 60 & 0 & 40 & 0 \\
Y22 & 60 & 0 & 40 & 0 \\
X3 & 50 & 0 & 0 & 50 \\
Y3 & 50 & 0 & 0 & 50 \\
X33 & 60 & 0 & 0 & 40 \\
Y33 & 60 & 0 & 0 & 40 \\
\hline
\end{tabular}

Xa, Xaa denote extruded flour at Temperature: Moisture =120:10.12 whereas Ya and Yaa denote extruded flour at Temperature: moisture $=140: 14.30$ as indicated by run 1 and 2 in table 2 where $a=1,2,3$.

\section{F. Determination of Proximate and Nutritional Composition}

The moisture, ash, total fat, dietary fiber, Vitamin A and C of banana-based flours were determined using standard methods. Moisture content was determined using the oven drying method by drying at $105{ }^{\circ} \mathrm{C}$ overnight [11]. Total fat content was determined using the Soxhlet method [11]. The ash content was determined using a method described by [12] at $550{ }^{\circ} \mathrm{C}$ for $6 \mathrm{~h}$ in a furnace. The dietary fiber content of the mixed flours was determined using the FOSS Fibertec 2010. 


\section{G. Sensory Acceptability of the Extruded Flour Soups}

Overall acceptability of the flours was investigated using a standard sensory evaluation method at the sensory laboratory at SFTNB. The soup samples were coded and then presented to the panel for evaluation [13]. The soup was evaluated for its color, appearance, aroma and texture on a 9-point hedonic scale by an untrained panel of 30 people. The 9-point hedonic scale grading was as follows: "1" Dislike extremely, "2" Dislike very much, "3" Dislike moderately, "4" Dislike slightly, "5" Neither like nor dislike, "6" Like slightly, "7" Like moderately, "8" Like very much and "9" Like extremely. The panelists were given mineral water to rinse their pallet in between testing of samples.

\section{H. Data Analysis}

All experiments were conducted in triplicate. Statistical analysis of the data was performed by analysis of variance (ANOVA), using SPSS software (IBM statistics, version 20). A probability value of $\mathrm{p} \leq 0.05$ was considered to denote statistical significance. All data were presented as mean values \pm standard deviation (SD). Regression analysis was performed to indicate the relationship between the tested parameters and formulations. The effect of extrusion on dependent parameters (Overall acceptability, Fat content, Ash content, Fibre, Vitamin C and Vitamin A) was analyzed using the second order approximation model (1) [13] and the response surface plots extracted using Design expert (Stat Ease, Version 11.1.0.1, Minneapolis, USA). The optimal product was selected using Desirability Function Approach:

$$
Y=B_{0}+\sum_{i-1}^{k} B_{i} X_{i}+\sum_{i-1}^{k} B_{i i} X_{i}^{2}+\sum_{i-1}^{k} B_{i j} X_{i} X_{j}+\varepsilon
$$

where $\mathrm{Y}$ is the response function, $\mathrm{X}_{\mathrm{i}}$ is the feed moisture content, $\mathrm{X}_{\mathrm{j}}$ is the barrel temperature, $\varepsilon$ is the random error, $B_{\mathrm{o}}$ the center point of the system, $B_{i}, B_{i i}$, and $B_{i j}$ represent the coefficients of the linear, quadratic and interactive effects of the independent variables respectively, and $\mathrm{X}_{\mathrm{i}}, \mathrm{X}_{\mathrm{i}}{ }^{2}$, and $\mathrm{X}_{\mathrm{i}} \mathrm{X}_{\mathrm{j}}$ represent the linear, quadratic and interactive effects, respectively of the independent variable.

\section{RESULTS AND DISCUSSIONS}

\section{A. Reconstitution of Flours}

The resultant paste was laid on clear aluminum foils for observation as shown in Fig. 1.

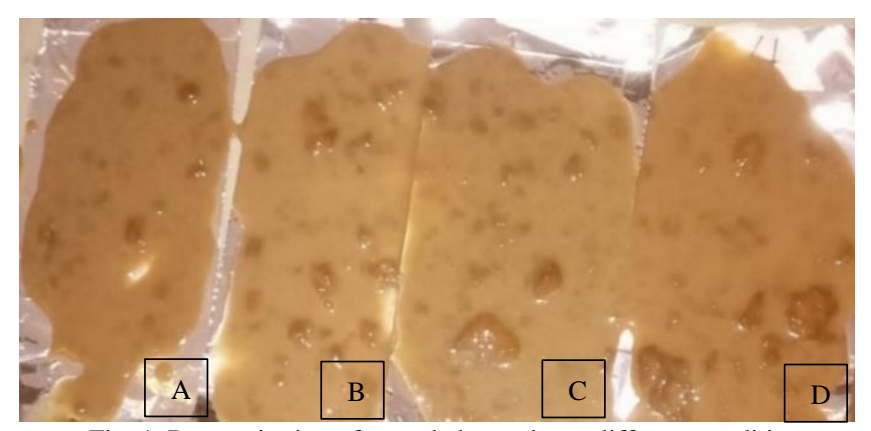

Fig. 1. Reconstitution of extruded samples at different conditions.

The samples coded A and B were consistent in mixing compared to samples C and D. Moving from left to right, there was an observed reduction in mixing due to increased extrusion temperatures. Sample D had the biggest clods compared to other samples. The tasting using mouth feel and flavor eliminated samples C and D whereas samples A and B were selected for further improvement explaining their choice in Table IV.

\section{B. Proximate and Nutritional Composition of the Samples} TABLE V: PROXIMATE COMPOSITION OF EXTRUDED SAMPLES

\begin{tabular}{|c|c|c|c|c|c|c|}
\hline $\begin{array}{c}\text { Sample } \\
\text { code* }\end{array}$ & $\operatorname{MC}(\%)$ & Fiber $(\%)$ & Fat $(\%)$ & Ash (\%) & Vit C (mg/100g) & $\begin{array}{l}\text { Vit A RAE } \\
\text { mg/100g }\end{array}$ \\
\hline $\mathrm{X} 1$ & $9.32 \pm 0.01^{\mathrm{de}}$ & $5.11 \pm 0.16^{\text {bc }}$ & $13.61 \pm 0.43^{\text {cde }}$ & $3.93 \pm 0.00^{\mathrm{a}}$ & $9.26 \pm 0.96^{\mathrm{ab}}$ & $0.74 \pm 0.02^{\mathrm{ab}}$ \\
\hline Y1 & $8.53 \pm 0.03^{\mathrm{a}}$ & $5.22 \pm 0.06^{\mathrm{c}}$ & $12.72 \pm 0.82^{\mathrm{bc}}$ & $4.14 \pm 0.03^{\mathrm{abcd}}$ & $11.45 \pm 0.87^{\mathrm{cde}}$ & $1.18 \pm 0.03^{\mathrm{e}}$ \\
\hline $\mathrm{X} 11$ & $8.88 \pm 0.01^{b c}$ & $5.34 \pm 0.28^{\mathrm{cd}}$ & $12.41 \pm 0.51^{\mathrm{bc}}$ & $4.26 \pm 0.64^{\mathrm{abcd}}$ & $10.71 \pm 0.85^{\mathrm{bcd}}$ & $0.84 \pm 0.03^{\mathrm{abc}}$ \\
\hline Y11 & $8.82 \pm 0.03^{\mathrm{ab}}$ & $4.08 \pm 0.08^{\mathrm{a}}$ & $13.01 \pm 0.82^{\text {bcd }}$ & $4.01 \pm 0.00^{\mathrm{ab}}$ & $13.14 \pm 0.82^{\mathrm{e}}$ & $0.97 \pm 0.01^{\mathrm{cd}}$ \\
\hline $\mathrm{X} 2$ & $9.25 \pm 0.03^{\mathrm{d}}$ & $3.67 \pm 0.21^{\mathrm{a}}$ & $14.74 \pm 0.08^{\mathrm{ef}}$ & $4.15 \pm 0.06^{\mathrm{abcd}}$ & $9.79 \pm 1.16^{\mathrm{abc}}$ & $0.76 \pm 0.02^{\mathrm{ab}}$ \\
\hline $\mathrm{Y} 2$ & $9.20 \pm 0.04^{\mathrm{cd}}$ & $3.68 \pm 0.01^{\mathrm{a}}$ & $14.50 \pm 0.37^{\mathrm{de}}$ & $4.36 \pm 0.18^{\mathrm{abcd}}$ & $10.65 \pm 0.60^{\mathrm{bcd}}$ & $0.76 \pm 0.00^{\mathrm{ab}}$ \\
\hline $\mathrm{X} 22$ & $9.37 \pm 0.19^{\mathrm{de}}$ & $5.76 \pm 0.26^{\mathrm{de}}$ & $12.49 \pm 0.38^{\mathrm{bc}}$ & $4.03 \pm 0.05^{\mathrm{abc}}$ & $10.11 \pm 0.61^{b c}$ & $0.70 \pm 0.01^{\mathrm{a}}$ \\
\hline Y22 & $9.47 \pm 0.10^{\mathrm{de}}$ & $7.59 \pm 0.07^{\mathrm{f}}$ & $12.25 \pm 0.96^{\mathrm{bc}}$ & $4.19 \pm 0.26^{\text {abcd }}$ & $7.83 \pm 0.96^{\mathrm{a}}$ & $0.98 \pm 0.25^{\mathrm{cd}}$ \\
\hline $\mathrm{X} 3$ & $10.52 \pm 0.07^{\mathrm{g}}$ & $4.61 \pm 0.12^{b}$ & $11.89 \pm 0.72^{\mathrm{b}}$ & $4.75 \pm 0.11^{\mathrm{d}}$ & $21.98 \pm 0.73^{\mathrm{g}}$ & $1.08 \pm 0.04^{\mathrm{de}}$ \\
\hline Y3 & $9.62 \pm 0.26^{\mathrm{ef}}$ & $5.81 \pm 0.07^{\mathrm{de}}$ & $16.38 \pm 0.45^{\mathrm{f}}$ & $4.64 \pm 0.03^{\mathrm{cd}}$ & $12.13 \pm 1.37^{\mathrm{de}}$ & $1.12 \pm 0.07^{\mathrm{de}}$ \\
\hline X33 & $10.21 \pm 0.16^{\mathrm{g}}$ & $5.09 \pm 0.02^{\mathrm{bc}}$ & $9.18 \pm 0.17^{\mathrm{a}}$ & $4.57 \pm 0.14^{\mathrm{bcd}}$ & $18.17 \pm 1.49^{\mathrm{f}}$ & $1.08 \pm 0.27^{\mathrm{de}}$ \\
\hline Y33 & $9.83 \pm 0.04^{\mathrm{f}}$ & $6.02 \pm 0.32^{\mathrm{e}}$ & $9.12 \pm 0.23^{\mathrm{a}}$ & $4.42 \pm 0.00^{\mathrm{abcd}}$ & $12.88 \pm 1.21^{\mathrm{e}}$ & $0.87 \pm 0.01^{\mathrm{bc}}$ \\
\hline
\end{tabular}

Values represent mean \pm standard deviation $(\mathrm{n}=3)$. Means in the same column with different superscripts are significantly different $(\mathrm{p}<0.05)$. $*$ Sample codes $\mathrm{Xi}(50: 50)$ and Xii (60:40) represent Sample 1 (S1) for Extruded flour: Vegetable Flour respectively while Yj (50:50) and Yjj (60:40) represent Sample 2 (S2) for Extruded flour: Vegetable Flour corresponding to Runs 1 and 2 respectively indicated as indicated in Table II.

The moisture content varied between 8.53 and 10.52 . Moisture content increases with composition of chicken in the samples indicating that the addition of chicken leads to storage of more water molecules. The formulation X3 (Extruded flour: Vegetable-chicken flour with chicken at $20 \%=50: 50$ ) had the largest moisture content while Y1 (Extruded flour: vegetable-chicken flour with chicken composition at $0 \%=60: 40$ ) had the lowest moisture content. Fiber content (FC) varied between 3.67 and 7.6\%. The sample Y22 (Extruded flour: vegetable-chicken flour with chicken at $0 \%=60: 40$ ) had the highest fibers. Fiber content in the samples varied according to (2):

$$
\begin{aligned}
& \text { Fiber }=-9.97+0.11 \mathrm{X} 1+0.33 \mathrm{X}_{3}-0.78 \mathrm{X}_{5}-0.002 \mathrm{X}_{1} \mathrm{X}_{4} \\
& +0.001 \mathrm{X}_{3} \mathrm{X}_{5}+0.003 \mathrm{X}_{5}{ }^{2}\left(\mathrm{R}^{2}=0.48\right)
\end{aligned}
$$

The model explains $48 \%$ of variability. Barrel temperature (X1) and extruded flour (X3) had a positive effect on fiber content of the soup indicating that the increase in temperature and extruded flour increases the fiber content of the formulations as shown in Fig. 2. The increase in chicken levels $\left(\mathrm{X}_{5}\right)$ in the soup reduces the fiber content of the soup. 


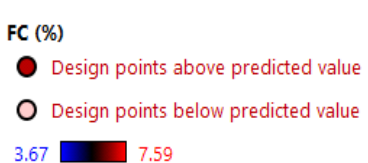

$3.67 \square 7.59$

$\mathrm{X} 1=\mathrm{A}:$ Temperature

$\mathrm{X} 2$ = B: Moisture Content

Actual Factors

C: Chicken composition $=20$

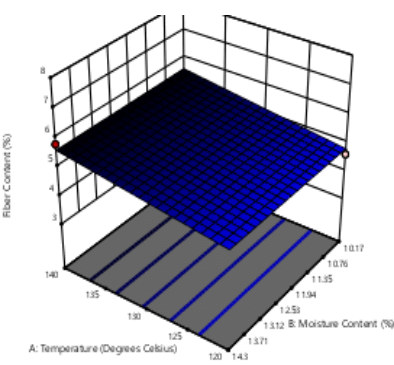

Fig. 2. Response surface plots showing effect of varying different levels of moisture and temperature and chicken composition on Fiber Content (FC).

The fat content varied between 9.12 and $16.38 \%$. Sample Y3 (Extruded flour: vegetable-chicken flour with chicken at $20 \%=60: 40$ ) had the highest fat content whereas sample Y3 (Extruded flour: vegetable-chicken flour with chicken at 20\%=50:50) had the lowest fat content. Fat content increases with extrusion temperature. The addition of chicken thus leads to storage of more fat molecules in the samples. There is a general increase in the fat content of the samples compared to unextruded flour samples according to (3):

$$
\begin{aligned}
& \text { Fat }=-34.7+0.39 \mathrm{X}_{1}+0.87 \mathrm{X}_{3}+0.64 \mathrm{X}_{5}-0.007 \mathrm{X}_{1} \mathrm{X}_{3} \\
& +0.006 \mathrm{X}_{1} \mathrm{X}_{5}-0.022 \mathrm{X}_{3} \mathrm{X}_{5}-0.013 \mathrm{X}_{5}{ }^{2}\left(\mathrm{R}^{2}=0.88\right)
\end{aligned}
$$

The coefficient of variation explained up to $88 \%$ of variability. Barrel temperature $\left(X_{1}\right)$, extruded flour $\left(\mathrm{X}_{3}\right)$ and chicken levels $\left(\mathrm{X}_{5}\right)$ had a positive linear effect on fat content of the soup as indicated in Fig. 3. The increase in temperature, extruded flour and chicken levels had a significant increase in the fat composition of the soup $(p<0.05)$. Increase in chicken composition increases the soup's fat content because of its high fat value.


C: Chicken composition $=20$

Fig. 3. Response surface plot showing effect of varying different levels of moisture, temperature and chicken composition on Fat content.

The ash content varied between 3.93 and $4.75 \%$ in the order of increasing chicken composition. The sample formulation $\mathrm{X}_{3}$ (Extruded flour: vegetable-chicken flour with chicken at 20\%=50:50) had the highest ash content while $X_{1}$ (Extruded flour: vegetable-chicken flour with chicken at $0 \%=50: 50$ ) had the lowest ash content. The addition of chicken improves on the quantity of ashes in the samples according to (4):

$$
\begin{aligned}
& \text { Ash }=-2.56+0.045 \mathrm{X}_{1}+0.125 \mathrm{X}_{3}+0.11 \mathrm{X}_{5}-0.001 \mathrm{X}_{1} \mathrm{X}_{3} \\
& -0.0002 \mathrm{X}_{1} \mathrm{X}_{5}-0.002 \mathrm{X}_{1} \mathrm{X}_{5}+0.002 \mathrm{X}_{5}^{2}\left(\mathrm{R}^{2}=0.91\right)
\end{aligned}
$$

The $\mathrm{R}^{2}$ of the model is good and explained up to $91 \%$ of variability. Barrel temperature $\left(X_{1}\right)$, extruded flour $\left(\mathrm{X}_{3}\right)$, chicken level $\left(\mathrm{X}_{5}\right)$ had a positive linear effect on the ash content of the soups as indicated in Fig. 4. The increase in temperature, extruded flour and chicken level caused a significant increment in ash content of the soup.
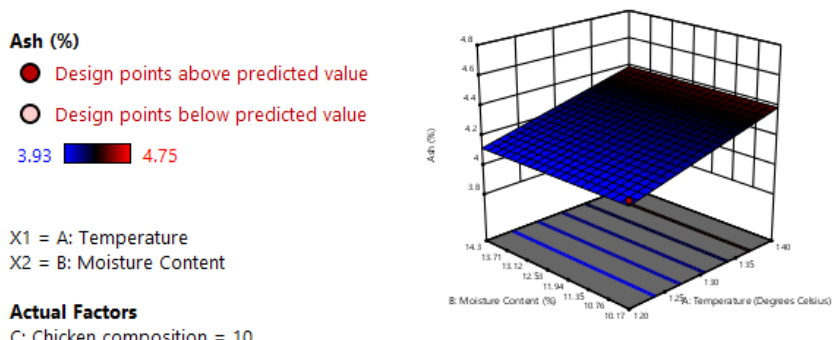

C: Chicken composition $=10$

Fig. 4. Response surface plots showing effect of varying different levels of moisture and temperature and chicken composition on Ash content.

The vitamin A content varied between 0.70 and 1.18 RAE $\mathrm{mg} / 100 \mathrm{~g}$. The sample $\mathrm{Y}_{1}$ (Extruded flour: vegetable-chicken flour with chicken at $0 \%=50: 50$ ) had the highest Vitamin A while $\mathrm{X}_{22}$ (Extruded flour: vegetable-chicken flour with chicken at $10 \%=60: 40$ ) had the lowest Vitamin A content among the samples. Vitamin A increases with increases in extrusion temperature. Vitamin A varied according to (5):

$$
\begin{aligned}
& \text { Vit } A=-4.15+0.04 X_{1}+0.07 X_{3}+0.12 X_{5}-0.0005 X_{1} X_{3} \\
& -0.001 X_{1} X_{5}-0.0009 X_{3} X_{5}+0.002 X_{5}^{2}\left(R^{2}=0.73\right)
\end{aligned}
$$
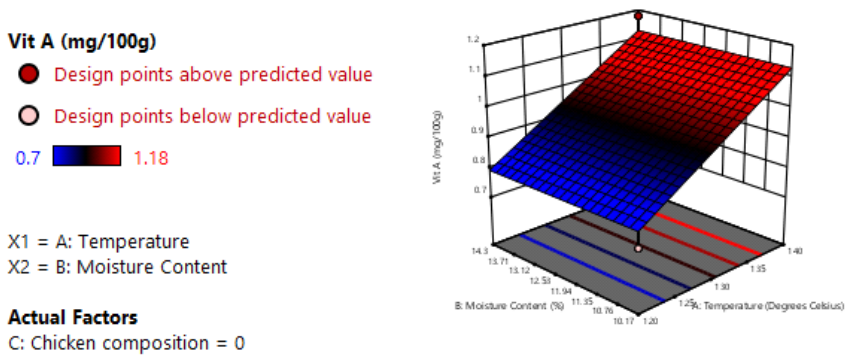

Fig. 5. Response surface plots showing effect of varying different levels of moisture and temperature and chicken composition on Vitamin A (Vit A).

The $\mathrm{R}^{2}$ of the model is good and explained up to $73 \%$ of variability. Barrel temperature $\left(X_{1}\right)$, extruded flour $\left(\mathrm{X}_{3}\right)$ and chicken level $\left(\mathrm{X}_{5}\right)$ had a positive linear and negative interactive effect on Vitamin A composition of the soup whereas chicken levels had a positive quadratic effect on vitamin A content as described by Fig. 5. Increase in temperature increases the vitamin A availability [14].

The vitamin $\mathrm{C}$ content in samples varied between 7.83 and $21.98 \mathrm{mg} / 100 \mathrm{~g}$. The sample X3 (Extruded flour: vegetablechicken flour with chicken at $20 \%=50: 50$ ) had the highest Vitamin C. Vitamin C increases with increase in composition of chicken in the samples. There is a general increase in samples Vitamin C after extrusion of flours. Vitamin C in the samples varied according to (6):

$$
\begin{aligned}
& \text { Vit } C=49.73-0.38 X_{1}-0.97 X_{3}+3.54 X_{5}+0.01 X_{1} X_{3} \\
& -0.024 X_{1} X_{5}-0.02 X_{3} X_{5}+0.04 X_{5}^{2}\left(R^{2}=0.95\right)
\end{aligned}
$$

The $\mathrm{R}^{2}$ of the model is good and explained up to $95 \%$ of variability. Barrel temperature $\left(X_{1}\right)$, Extruded flour $\left(\mathrm{X}_{3}\right)$ had a negative linear effect on Vitamin $C$ composition of the soup as described in Fig. 6. The increase in temperature reduces 
Vitamin C composition of the soup. This is true since Vitamin $\mathrm{C}$ is a temperature sensitive
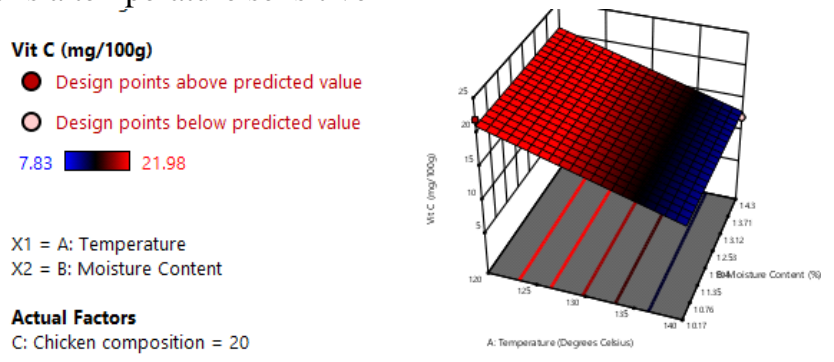

Fig. 6. Response surface plots showing effect of varying different levels of moisture and temperature and chicken composition on Vitamin C (Vit C).

\section{Sensory Evaluation}

Sample Y22 (Extruded flour: vegetable-chicken flour with chicken at $10 \%=60: 40)$ had the largest appearance of 7.4 while Y3 (Extruded flour: vegetable-chicken flour with chicken at 20\%=50:50) had the least appearance of 6.50. The significance test indicates no difference in the samples appearance $(\mathrm{p}<0.05)$. Sample X22 (Extruded flour: vegetable-chicken flour with chicken at 10\%=60:40) had the highest scores on aroma and mouth feel of 7.13 and 7.47 respectively which represents like moderately on the hedonic scale. The sample formulation X3 (Extruded flour: vegetablechicken flour with chicken at $20 \%=50: 50$ ) had the best scores on taste and Overall acceptability of 7.43 and 7.93 which represents like very much on the hedonic scale, thus the most preferred sample. Sample formulation Y2 (Extruded flour: vegetable-chicken flour with chicken at $10 \%=50: 50$ ) had the best scores for color (7.00) which represent like moderately on the hedonic scale. However, appearance, color, texture, aroma, mouth feel, taste and overall acceptability indicate that there is no statistically significant difference between the formulations at $\mathrm{p} \leq 0.05$. The Overall acceptability, OA varied according to (7):

$$
\begin{aligned}
& \mathrm{OA}=13.64-0.04 \mathrm{X}_{1}-0.11 \mathrm{X}_{3}-0.03 \mathrm{X}_{5}+0.0007 \mathrm{X}_{1} \mathrm{X}_{3}(7) \\
& +0.0005 \mathrm{X}_{1} \mathrm{X}_{5}+0.001 \mathrm{X}_{3} \mathrm{X}_{5}-0.004 \mathrm{X}_{5}^{2}\left(\mathrm{R}^{2}=0.34\right)
\end{aligned}
$$

Barrel temperature $\left(X_{1}\right)$, extruded flour $\left(\mathrm{X}_{3}\right)$ and chicken level $\left(\mathrm{X}_{5}\right)$ had a negative linear effect on Overall acceptability as indicated in Fig. 7. The interactive effects between temperature-extruded flour, temperature-chicken level and extruded flour-chicken level were positive. The increase in temperature, extruded flour and chicken level caused a nonsignificant reduction in acceptability of the soup.
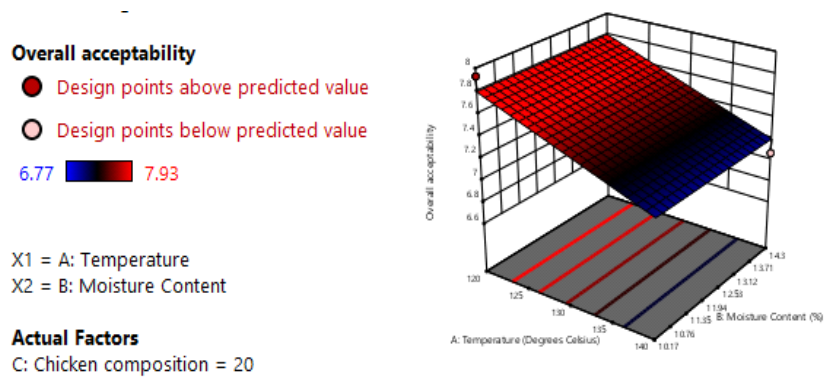

Fig. 7. Response surface plots showing effect of varying different levels of moisture and temperature and chicken composition on Overall acceptability $(\mathrm{OA})$.

\begin{tabular}{|c|c|c|c|c|c|c|c|}
\hline FC* & Appearance & Color & Texture & Aroma & Mouth feel & Taste & $\mathrm{OA}$ \\
\hline $\mathrm{X} 1$ & $6.53 \pm 1.94^{\mathrm{a}}$ & $6.77 \pm 2.18^{\mathrm{a}}$ & $6.53 \pm 1.41^{\mathrm{a}}$ & $6.33 \pm 1.94^{\mathrm{a}}$ & $6.80 \pm 1.65^{\mathrm{a}}$ & $6.60 \pm 1.71^{\mathrm{a}}$ & $7.20 \pm 1.58^{\mathrm{a}}$ \\
\hline $\mathrm{X} 11$ & $6.53 \pm 1.83^{\mathrm{a}}$ & $6.70 \pm 1.76^{\mathrm{a}}$ & $6.57 \pm 1.45^{\mathrm{a}}$ & $6.70 \pm 1.62^{\mathrm{a}}$ & $6.43 \pm 1.63^{\mathrm{a}}$ & $6.00 \pm 1.93^{\mathrm{a}}$ & $6.97 \pm 1.77^{\mathrm{a}}$ \\
\hline $\mathrm{X} 2$ & $6.93 \pm 1.11^{\mathrm{a}}$ & $6.67 \pm 1.49^{\mathrm{a}}$ & $6.07 \pm 1.41^{\mathrm{a}}$ & $6.43 \pm 1.48^{\mathrm{a}}$ & $6.57 \pm 1.79^{\mathrm{a}}$ & $6.93 \pm 1.57^{\mathrm{a}}$ & $6.80 \pm 1.73^{\mathrm{a}}$ \\
\hline $\mathrm{X} 22$ & $6.53 \pm 1.63^{\mathrm{a}}$ & $6.13 \pm 1.55^{\mathrm{a}}$ & $6.47 \pm 1.36^{\mathrm{a}}$ & $7.13 \pm 1.81^{\mathrm{a}}$ & $7.47 \pm 1.25^{\mathrm{a}}$ & $7.17 \pm 1.42^{\mathrm{a}}$ & $7.13 \pm 1.78^{\mathrm{a}}$ \\
\hline $\mathrm{X} 3$ & $7.30 \pm 1.47^{\mathrm{a}}$ & $7.00 \pm 1.44^{\mathrm{a}}$ & $6.87 \pm 1.53^{\mathrm{a}}$ & $6.73 \pm 1.17^{\mathrm{a}}$ & $7.00 \pm 1.58^{a}$ & $7.43 \pm 1.19^{\mathrm{a}}$ & $7.93 \pm 1.11^{\mathrm{b}}$ \\
\hline X33 & $6.87 \pm 1.17^{\mathrm{a}}$ & $6.30 \pm 1.24^{\mathrm{a}}$ & $6.87 \pm 0.86^{\mathrm{a}}$ & $7.13 \pm 1.41^{\mathrm{a}}$ & $7.23 \pm 1.28^{\mathrm{a}}$ & $7.40 \pm 1.16^{\mathrm{a}}$ & $6.77 \pm 1.22^{\mathrm{a}}$ \\
\hline Y1 & $6.67 \pm 1.27^{\mathrm{a}}$ & $6.67 \pm 1.42^{\mathrm{a}}$ & $6.63 \pm 1.45^{\mathrm{a}}$ & $6.93 \pm 1.26^{\mathrm{a}}$ & $7.07 \pm 1.60^{\mathrm{a}}$ & $7.07 \pm 1.41^{\mathrm{a}}$ & $7.30 \pm 1.02^{\mathrm{ab}}$ \\
\hline Y11 & $7.17 \pm 1.37^{\mathrm{a}}$ & $6.70 \pm 1.34^{\mathrm{a}}$ & $6.70 \pm 1.29^{\mathrm{a}}$ & $6.83 \pm 1.42^{\mathrm{a}}$ & $7.07 \pm 1.44^{\mathrm{a}}$ & $6.87 \pm 1.28^{\mathrm{a}}$ & $7.20 \pm 1.67^{\mathrm{ab}}$ \\
\hline $\mathrm{Y} 2$ & $7.00 \pm 1.62^{\mathrm{a}}$ & $7.17 \pm 1.53^{\mathrm{a}}$ & $6.63 \pm 1.47^{\mathrm{a}}$ & $6.97 \pm 1.27^{\mathrm{a}}$ & $6.43 \pm 1.33^{a}$ & $6.80 \pm 1.61^{\mathrm{a}}$ & $6.77 \pm 1.10^{\mathrm{a}}$ \\
\hline Y22 & $7.40 \pm 1.04^{\mathrm{a}}$ & $6.37 \pm 1.19^{\mathrm{a}}$ & $6.20 \pm 1.54^{\mathrm{a}}$ & $6.60 \pm 1.50^{\mathrm{a}}$ & $6.77 \pm 1.63^{\mathrm{a}}$ & $7.17 \pm 1.21^{\mathrm{a}}$ & $7.33 \pm 1.21^{\mathrm{a}}$ \\
\hline Y3 & $6.50 \pm 1.98^{\mathrm{a}}$ & $6.83 \pm 1.21^{\mathrm{a}}$ & $6.37 \pm 1.45^{\mathrm{a}}$ & $6.53 \pm 1.50^{\mathrm{a}}$ & $6.77 \pm 1.57^{\mathrm{a}}$ & $7.07 \pm 1.31^{\mathrm{a}}$ & $7.07 \pm 1.41^{\mathrm{a}}$ \\
\hline Y33 & $6.70 \pm 1.84^{\mathrm{a}}$ & $6.73 \pm 1.36^{\mathrm{a}}$ & $6.37 \pm 1.73^{\mathrm{a}}$ & $6.00 \pm 1.26^{\mathrm{a}}$ & $6.37 \pm 1.19^{\mathrm{a}}$ & $6.90 \pm 1.95^{\mathrm{a}}$ & $6.97 \pm 1.25^{\mathrm{a}}$ \\
\hline
\end{tabular}

TABLE VI: CONSUMER ACCEPTABILITY SCORES OF SOUPS FROM DIFFERENT FLOUR FORMULATIONS

Values represent mean \pm standard deviation $(\mathrm{n}=30)$. Means in the same column with different superscripts are significantly different $(\mathrm{p}<0.05)$. Formulation codes represent samples in the respective formulations indicated in Table IV.

\section{Optimal Solutions for Selection of the Final Product}

The Optimal formulation was obtained basing on extrusion temperature; moisture content combinations as well as incorporation of chicken in the samples using Desirability Function approach (DFA). The final product had a mixture composition of $50 \%$ extruded flour and $50 \%$ chicken vegetable flour extruded at $123.3{ }^{\circ} \mathrm{C}$ and $10.12 \%$ moisture content as indicated in Table VII at a desirability index of 0.56 . The product had an Overall acceptability of 7.10 and a Vitamin C content of $14.04 \mathrm{mg} / 100 \mathrm{~g}$ making it a nutritious product for the children between the 6 to 59 months.

\begin{tabular}{|c|c|c|c|c|c|c|c|c|c|c|c|c|c|c|}
\hline No & $\begin{array}{l}\text { Temp } \\
\left({ }^{\circ} \mathrm{C}\right)\end{array}$ & $\begin{array}{l}\text { M.C } \\
(\%) \\
\end{array}$ & $\begin{array}{c}\mathrm{EF} \\
(\mathrm{g} / 100 \mathrm{~g})\end{array}$ & $\begin{array}{l}\mathrm{VF} \\
(\%) \\
\end{array}$ & $\begin{array}{l}\mathrm{CL} \\
(\%)\end{array}$ & $\begin{array}{l}\mathrm{MC} \\
(\%)\end{array}$ & $\begin{array}{c}\text { Fiber } \\
(\%)\end{array}$ & $\begin{array}{l}\text { Fat } \\
(\%)\end{array}$ & $\begin{array}{l}\text { Ash } \\
(\%)\end{array}$ & $\begin{array}{c}\text { Vit C } \\
(\mathrm{mg} / 1000 \mathrm{~g})\end{array}$ & $\begin{array}{c}\text { Vit A } \\
(\mathrm{RAE} \mathrm{mg} / 100 \mathrm{~g})\end{array}$ & $\mathrm{OA}$ & Desirability & \\
\hline 1 & 123.3 & 10.12 & 50.0 & 50.0 & 16.6 & 9.825 & 5.4 & 10.1 & 4.4 & 14.04 & 0.90 & 7.1 & 0.596 & Selected \\
\hline 2 & 122.6 & 10.12 & 50.1 & 49.9 & 16.3 & 9.814 & 5.4 & 10.1 & 4.4 & 14.02 & 0.90 & 7.1 & 0.595 & \\
\hline 3 & 128.7 & 10.12 & 50.1 & 49.9 & 17.3 & 9.810 & 5.6 & 10.2 & 4.4 & 13.30 & 0.91 & 7.1 & 0.593 & \\
\hline 4 & 132.0 & 10.12 & 50.0 & 50.0 & 17.4 & 9.764 & 5.8 & 10.3 & 4.3 & 12.50 & 0.90 & 7.2 & 0.589 & \\
\hline 5 & 140.0 & 10.12 & 50.7 & 49.3 & 3.83 & 8.928 & 4.8 & 12.7 & 4.0 & 10.53 & 0.88 & 7.2 & 0.545 & \\
\hline 6 & 139.9 & 10.12 & 57.2 & 52.8 & 2.46 & 8.909 & 4.7 & 13.2 & 4.0 & 10.74 & 0.91 & 7.2 & 0.513 & \\
\hline
\end{tabular}

TABLE VII: OPTIMAL SOLUTIONS FOR AN ACCEPTABLE AND NUTRITIOUS PRODUCT 


\section{E. Model Validation}

Three formulations whose test outcomes are known were randomly selected, the optimal product S1 (Table VII) (Temperature: Moisture content: Extruded Flour: Vegetable flour: Chicken levels $=123.3: 10.12: 60: 50: 16.6)$, the next optimal product (Table VII), S2 (Temperature: Moisture content: Extruded Flour: Vegetable flour: Chicken levels = 122.6:10.12:60:49.9:16.3), the formulation (X1) from Table IV S3(Temperature: Moisture content: Extruded Flour: Vegetable flour: Chicken levels $=120: 10.12: 50: 50: 0$ ) were tested with the model equations for selected parameters and the results presented in Table VIII.

TABLE VIII: TESTING THE VALIDITY OF MODELS

\begin{tabular}{|c|c|c|c|c|c|c|}
\hline codes & Fiber $(\%)$ & Fat $(\%)$ & Ash (\%) & Vit C $(\mathrm{mg} / 100 \mathrm{~g})$ & $\begin{array}{c}\text { Vit A } \\
(\mathrm{RAE} \mathrm{mg/100g)} \\
\end{array}$ & $\mathrm{OA}$ \\
\hline S1 & $6.8(5.4)$ & $11.2(10.1)$ & $4.92(4.4)$ & $19.4(14.04)$ & $1.21(0.90)$ & $7.3(7.1)$ \\
\hline $\mathrm{S} 2$ & $6.8(5.4)$ & $11.3(10.1)$ & $4.90(4.4)$ & $19.3(14.02)$ & $1.19(0.91)$ & $7.3(7.1)$ \\
\hline S3 & $7.7(5.1)$ & $13.6(13.6)$ & $3.09(3.9)$ & $15.6(9.26)$ & $1.15(0.74)$ & $7.5(7.2)$ \\
\hline
\end{tabular}

The results indicate that there are slight differences between model values and tested values (in parentheses). The observed differences are due to errors produced from rounding off of coefficient terms in the models. The models can be used to make predictions about the response for given levels of each factor. The levels should be specified in the original units for each factor to be fed into the design expert program. These models should not be used to determine the relative impact of each factor since the coefficients are scaled to accommodate the units of each factor and the intercept is not at the center of the design space. A comparison of the laboratory value with model value for some selected responses are as shown in Table IX. The observed differences could be attributed to slight differences in sample preparation especially during sample extrusion.

TABLE IX: COMPARISON OF LABORATORY RESULTS AND MODEL RESULTS FOR THE SELECTED SAMPLE

\begin{tabular}{ccc}
\hline Response & Laboratory Value & Model Value \\
\hline Moisture \% & $10.05 \pm 0.14$ & 10.12 \\
Vitamin A & $1.04 \pm 0.138$ & 0.90 \\
RAE(mg/100g) & $10.72 \pm 0.19$ & 10.1 \\
Fat \% & $4.86 \pm 0.03$ & 4.4 \\
Ash \% &
\end{tabular}

\section{CONCLUSION AND RECOMMENDATIONS}

The purpose of this study was to evaluate the effect of extrusion conditions on Overall Acceptability and nutritional properties as well as functional properties of the product. The study has demonstrated that extrusion conditions being high temperature short time (HTST) process destroys flavors within samples thus requiring freshly cooked ingredients to improve on its acceptability. Increasing extrusion temperature improves the fiber content, Vitamin A and C while incorporation of chicken increases fat content. The results indicated that there is a significant difference $(p<0.05)$ in vitamin $\mathrm{A}$ and $\mathrm{C}$, fibres and ash content as a result of changing extrusion conditions. The changes are also a result of altering the vegetable-chicken composition from $0 \%$ to $20 \%$. The optimum extrusion conditions were temperature; moisture combinations of $123.3^{\circ} \mathrm{C}$ and $10.12 \%$ respectively as shown in Table VII. Flour combination was extruded flour: Vegetable flour: Chicken level= 60:50:16.6. The Overall acceptability, fiber content, fat content, Ash content, Vitamin $\mathrm{C}$ and Vitamin A composition of the optimum flour was at $7.1,5.4 \%, 10.1 \%, 4.4 \%, 14.09 \mathrm{~g} / 100 \mathrm{~g}$ and $0.90 \mathrm{mg} / 100 \mathrm{~g}$ respectively. These values indicate that Overall acceptability and nutritional and physical chemical properties improve with the increase in the levels of Chicken-vegetable composition. Since the final product is composed of moisture which favor growth of molds and bacteria, determination of the final product shelf life has been recommended to be carried out. The final product should be stored at a temperature of $4{ }^{\circ} \mathrm{C}$ to prolong its shelf life once determined.

\section{ACKNOWLEDGMENT}

This study was funded by the Federal Ministry of Education and Research (BMBF), Germany through the Reduction of Post-Harvest Losses and Value Addition in East African Food Value Chains (RELOAD). The Authors also acknowledge Associate Professor Susan Balaba Tumwebaze of Makerere University, School of Forestry and Natural Resources Conservation for managing the funds of this project.

\section{REFERENCES}

[1] K. B. Filli, I. Nkama, and V. A. Jideani, "The Effect of Extrusion Conditions on the Physical and Functional Properties of Millet Bambara Groundnut Based Fura," Am. J. Food Sci. Technol., vol. 1, no. 4, pp. 87-101, 2013, doi: 10.12691/ajfst-1-4-5.

[2] S. James and T. U. Nwabueze, "Quality Evaluation Of Extruded Full Fat Blend Of African Breadfruit-Soybean-Corn Snack," Int. J. Sci. Technol. Res. Vol., vol. 2, no. 9, 2013.

[3] S. Yağci and F. Göğüş, "Response surface methodology for evaluation of physical and functional properties of extruded snack foods developed from food-by-products," J. Food Eng., vol. 86, no. 1, pp. 122-132, 2008, doi: 10.1016/j.jfoodeng.2007.09.018.

[4] S. Bhattacharya and M. Prakash, "Extrusion of blends of rice and chick pea flours: A response surface analysis," J. Food Eng., vol. 21, no. 3 , pp. 315-330, 1994, doi: 10.1016/0260-8774(94)90076-0.

[5] J. C. Cheftel, M. Kitagawa, and C. Queguiner, New Protein Texturization Processes by Extrusion Cooking at High Moisture Levels, vol. 8, no. 2. 1992.

[6] I. Björck and N. G. Asp, "The effects of extrusion cooking on nutritional value - A literature review," Journal of Food Engineering. 1983, doi: 10.1016/0260-8774(83)90016-X.

[7] R. Alonso, L. A. Rubio, M. Muzquiz, and F. Marzo, "The effect of extrusion cooking on mineral bioavailability in pea and kidney bean seed meals," Anim. Feed Sci. Technol., vol. 94, no. 1-2, pp. 1-13, 2001, doi: 10.1016/S0377-8401(01)00302-9.

[8] C. da S. Teba, E. M. M. da Silva, D. W. H. Chávez, C. W. P. de Carvalho, and J. L. R. Ascheri, "Effects of whey protein concentrate, feed moisture and temperature on the physicochemical characteristics of a rice-based extruded flour," Food Chem., vol. 228, pp. 287-296, 2017, doi: 10.1016/j.foodchem.2017.01.145.

[9] C. Sarawong, R. Schoenlechner, K. Sekiguchi, E. Berghofer, and P. K. W. Ng, "Effect of extrusion cooking on the physicochemical properties, resistant starch, phenolic content and antioxidant capacities of green 
banana flour," Food Chem., vol. 143, pp. 33-39, 2014, doi: 10.1016/j.foodchem.2013.07.081.

[10] O. A. Akande, D. Nakimbugwe, and I. M. Mukisa, "Optimization of extrusion conditions for the production of instant grain amaranth-based porridge flour,” Food Sci. Nutr., vol. 5, no. 6, pp. 1205-1214, 2017, doi: 10.1002/fsn3.513.

[11] AOAC, Association of Official Analytical Chemists. 1999. Official Methods of Analysis. AOAC, Washington, DC

[12] AOAC, "AOAC Official Methods of Analysis," Assoc. Off. Agric. Chem. Washington, D.C., vol. 1, no. 15th edition, pp. 136-138, 1990.

[13] F. T. Rodrigues, G. B. Fanaro, R. C. Duarte, A. C. Koike, and A. L. C. H. Villavicencio, "A sensory evaluation of irradiated cookies made from flaxseed meal," Radiat. Phys. Chem., vol. 81, no. 8, pp. $1157-$ 1159, 2012, doi: 10.1016/j.radphyschem.2012.02.001.

[14] S. Singh, S. Gamlath, and L. Wakeling, "Nutritional aspects of food extrusion: A review," Int. J. Food Sci. Technol., vol. 42, no. 8, pp. 916 929, 2007, doi: 10.1111/j.1365-2621.2006.01309.x.S. Chen, B. Mulgrew, and P. M. Grant, "A clustering technique for digital communications channel equalization using radial basis function networks," IEEE Trans. on Neural Networks, vol. 4, pp. 570-578, July 1993.

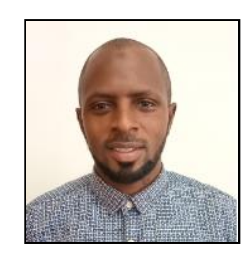

Paddy Ainebyona was born in Ssembabule Uganda on $21^{\text {st }}$ April, 1990. He holds a Bachelor degree in Agricultural Engineering from Makerere university Kampala, Uganda, 2016. His major focus was in post-harvest handling in to reduce the post-harvest losses in Uganda and developing countries.

He is currently a GRADUATE SCHOLAR at the department of Agricultural and Bio systems Engineering at Makerere university Kampala, Uganda. He has worked as a project administrator for several projects under the Makerere University Research and Innovation Fund (Mak-RIF), Kampala Uganda, since 2019. Ainebyona had been also a programs Coordinator at Engineers Without Borders USA Uganda Country Office, Kampala Uganda, 2018.

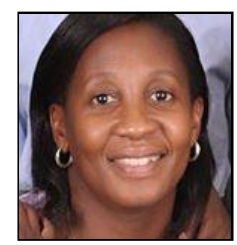

Dr. Julia Kigozi is trained as an Agricultural Engineer, specializing in Food Process Engineering. Julia attained a BSc. Agricultural Engineering from Makerere University, M(Eng) in Agricultural Engineering from University of Pretoria, and a PhD from Makerere University. She is a lecturer at Makerere University where she has been since 1997. She is involved in training and supervision of both undergraduate and graduate students in the Department of Agricultural and Biosystems Engineering. She specifically focusses on Post handling of crops, design and optimization of Food engineering operations, design of food processing equipment and plant Design. She has been involved in the design and construction of a soymilk machine, Groundnut Sheller, soya roaster, Soya steamer and fruit pulper, a batch pasteurizing equipment, vegetable/root chopping machine, Biomass Solar dryer, rice planter, soya steamer, continuous pasteurizer, juice packing machine, Refractance Window Dryer among others. Other areas of research have included; A study of the drying kinetics, quality and shelf stability of dried Rastrineobola Argentea (mukene fish) under varying processing and storage methods, development of Shelf table Fish sausage and Cracker, development of commercial products from sorghum, millet, matooke flour, Technical Inspection and Verification of Agricultural Equipment and Machineries. Julia also works with Agroprocessors to facilitate their growth in production; specifically, in setting up their infrastructure and optimizing their processing chain.

Dr. Julia is a member of Member of African Women in Science and Engineering (AWSE), American Society of Agricultural and Biological Engineers (ASABE), Pan African Society for Agricultural Engineering (AfroAgEng).

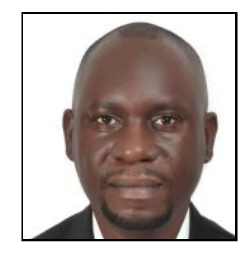

Ivan Muzira Mukisa was born in Entebbe, Uganda on November $28^{\text {th }} 1977$. He holds a PhD in Microbiology from the Norwegian University of Life Sciences, Aas, Norway, 2012. He also holds a Master of Science in Food Technology from Katholieke Universiteit Leuven and Universiteit Gent, Belgium, 2007. Ivan also holds a B. Sc in Food Science and Technology from Makerere University, Kampala, Uganda, 2003.
He has worked in the Department of Food Technology and Nutrition, Makerere University since 2004 to date and has risen through the ranks from Teaching Assistant to Associate Professor. He is currently the Head of Department, Food Technology and Nutrition, Makerere University. He has published 34 papers in peer reviewed journals in the last ten years. His research interests include: improving traditional fermentations and processing technologies; improving the processing, safety and stability of local foods and beverages; developing novel nutrient dense and acceptable food products using locally available raw materials; evaluating the potential beneficial health effects of foods; developing and evaluating the acceptability and stability of probiotic foods.

Assoc. Prof. Ivan Muzira Mukisa is a member of: the International Association for Food Protection (IAFP), the American Society for Microbiologists (ASM), and the Nutrition Society of Uganda (NSU). He is also a country Member for Uganda on the Codex Electronic Working Group 'Development of nutrient profiling for labelling (CCNFSDUnutrient-profiling)'. Ivan is also a member of the Codex Electronic Working Group 'Guidelines for the Control of Shiga Toxin-Producing $E$. Coli (STEC) in Raw Beef, Fresh Leafy Vegetables, Raw Milk and Raw Milk Cheeses, and Sprouts (CCFH-STEC2020)'. 